\title{
Pandemic Mitigaton in Javanes Culture
}

\author{
Sri Suhadjati ${ }^{1}$, Ahawan Fanani ${ }^{2}$ \\ Universitas Islam Negeri Walisongo Semarang ${ }^{1,2}$ \\ \{srieshan.21@gmail.com ${ }^{1}$, aristofanfanani@yahoo.com $\left.{ }^{2}\right\}$
}

\begin{abstract}
Pandemic in Javanese terms is called pageblug. Pageblugin Javanese culture, however, has wider meaning than that of English and refer to complicated mitigation approaches. Pandemiy could not solely treated as physical matter, without understanding social and cultural aspects. Pageblug in Javanese culture provides transdiciplinary approaches in which the understanding and the mitigation require physical as well as spiritual treatment. This paper aims to reveal the dimensions of pageblug. This article uses heuristic and cultural interpretation approaches of library sources. Pageblug according to Javanese society refers to all kinds of calamities, such as natural disasters, epidemy, and wars that result in large-scale casualties. Pageblug has broad dimensions, including physical, political and social conditions, natural signs and relationships with God. The mitigation approach to pageblug in Javanese culture involves physical treatment or medication (jamu), advice of intellegent person (wong pinter) with deep understanding (ngelmu), the discipline (laku) and prayer (japa). Therefore, to overcome the pandemic is to deal with human as physical and social subject as well as with human as spiritual one.
\end{abstract}

Key words: Pageblug; Pandemic; Mitigation; Javanese Culture

\section{Introduction}

The covid-19 pandemic that happens in Indonesia and other countries give birth to a wave of mass anxiety and economic crisis. So far, there has been no breakthrough made by any government to overcome the Covid-19 pandemic. This unfortunate situation is exacerbated by various confusing information about Covid-19 and by inappropriate response bu policy makers [1]. Government's recommendation to consume traditional herbal medicine and use certain necklaces are criticized by medical workers. Policies related to Covid-19 are seen inconsistent due to strong economic pressure and the decrease of public income that force Government to give less weight to health aspect.

The Efforts to limit social interaction by social distancing have been taken as standard procedure by many governments in the globe. Consequently, several social activities suffer from social limitation. Educational institutions, for instance, are laying off their students and changing the learning process to online learning, which leads to uncertainty in the assessment of students achievements and quality gaps between regions with high and low standard of education. The absence of learning interactions at school also reduces knowledge attainment $[2]$. 
Religious institutions are social institutions that face social distancing since the outbreak of Covid-19 in Indonesia. Many houses of worship were closed for two months and daily prayers are eliminated or limited. The religious leaders take important step by supporting social distancing promoted by Government which, according to Aula [3], strengthens of the authority of those religious leaders with the expense of religious activities.

Despite of hard measure directed to tackel the problem of Covid-19, there are ignorant attitude shown by part of communities. Communities in the villages or in remote area continue to carry out their daily social and religious activities without taking pandemic into account. To make worst, misleading information and conspiration theory, suspecting the pandemic as only false information fabricated by corruptors or capitalists, circulates among societies quickly through social media. The conditions add the uncertainty to the mitigation of Covid-19 and make society reluctant to really follow health protocol.

The ignorant attitude shown by some society to follow health protocol fully may be influenced by the latent paradigm related to pandemic. The social distancing policy in religious activities is sometimes deemed by society as awkward attitude, not to get closer to God in times people need to get gloser to Him. This religio-cultural point of view should not be underestimated because it relates to the way grasroot views pandemic and how they perceive the nature of pandemic. The attitude of the community regarding the plague cannot be separated from the cultural perception that connects the Covid-19 phenomenon with previous knowledge on it. In Javanese society, pandemic is equivalent to pageblug. Pageblug concept and mitigation has long root in Javanese culture. The concept of pageblug contributes to the way traditional people perceive pandemic and how it shlud be dealt with. These cultural aspects, however, fail to be dealt with under the regime of modern medical treatment.

This article is an attempt to describe the concept of the pageblug in Javanese society and the mitigation strategy known by them. This article is a literature study with a heuristic approach and interpretations of socio-cultural practices in Javanese society which are recorded in various documents.

\section{Result and Discussion}

\subsection{Conceptual Dimensions of the Pageblug}

Pagebluk has stems from the the root words bleg, blog, blug. In Baoesastra Djawa by W.J.S Poerwadarminta, the three words have the same meaning, namely the sound of a heavy object falling [4]. From this word, the word geblug comes up, which indicates the sound of falling goods and geblag, meaning people falling backwards. The word geblag then refers to the death of a person. In use, the word pageblug refers to the events of the death of people on a large scale. Pageblug is described as a condition in which people "sick in the afternoon and dead in the morning or sick in the morning and dead in the afternoon."

Disasters or pageblug, according to the Javanese, can be caused by natural disasters (flood, landslides, and volcanic eruptions), disease outbreaks, or famine (food shortages) due to crop failure, damage to crops by pests or a long dry season. Among the Javanese community, the occurrence of pageblug is believed to be a sign of macrocosmic disturbances related to microcosm, such as the death of Sultan Amangkurat I, Javanese Mataram King, was followed by pageblug. Pageblug is marked by the penomenon that many people get sick and die afterward. 
Pageblug is usually preceded by natural phenomena as its signs. The signs can be in the form of an animal sound, such as the sound of a crow as a sign of a dying person, or the appearance of a star (kemukus) which is believed to be the sign of disease outbreaks. Stars in Javanese society signify various things, including political sucession. The appearance of cubic latitude in Tuban on Saturday night, October 10, 2020, became a hot topic of conversation in the mass media because of the public's perception that the the kemukus was a sign of a pageblug or a natural disaster [5].

Fafirru Ilallah, an local Islamic work from Kediri in 1950, describes conditions marking miserable era, called ewuhaya or difficult era. This era is related to the chaotic social, political, and economic conditions that indicate the arrival of small and big apocalypse. The small apocalypse is the end of a social order, while the big apocalypse is the end of the world. Small doomsday is a necessary condition of social change called erucakra. Death will come in a chaotic social situation due to pupuh (final) war or big war and death due to natural disasters, such as the earth turned upside down (earthquake), drowning in the ocean and due to shock $[6]$.

The period of the Sangara in Primbon Jayabaya is actually the third cyle according to Old Javanese time. Sengara period (kali) is considered as the end of the human social order (doomsday) and as a turning point to the geninning next social order. Kali Sengara consists of several subperiods (kala), the famous one is Kala Bendu, the crazy era or the era of anger. People live hard at the time focusing on pursuing wealth, while poverty and crimes occur everywhere. At the end Sengara period, there would be the destruction of nature and the appearance of Imam Mahdi of messiah [7].

Pageblug, therefore, culturally refers to the occurrence of sudden deaths in time of war or natural disasters. Pageblug in war time is not solely caused by many casualties, but also because the strategy of war that involves psychological warfare or psywar by destroying health and water supplies. During Javanese Mataram Kingdom conquest of Surabaya in 16201625 , the Mataram army carried out a siege strategy, blocking part of the flowing river and destroying the water supply by inserting carcasses and palm fruit which resulted in the mass ill - such as experiencing coughing, itching, fever and stomach ache -- suffered by Surabaya residents [8].

Pageblug in Javanese worldview involves both inner and outer existances. Cosmologically, human soul and the natural soul reflect one another in which unrest in human life will influence the unrest of nature. Human's wrath signify the coming of the apocalypse (major damage) and, conversely, natural disasters mark human anxiety. A pageblug, then, is not merely an epidemy caused by phsyical creatures but also an indicator of human unrest.

Meanwhile, an epidemic or pandemic in the current sense refers to the spread of an infectious disease which results in death of people. Such epidemics occurred in Java in the at 20th century as a result of epidemics in Europe, like the outbreak of influenza in Java 19181920 [9]. The plague entered through the port of Buleleng and spread to Central Java and West Java. The outbreaks of the 20th century were not limited to influenza outbreaks. During 1911-1943, Samudra Eka Cipta found out that there were various epidemics that hit Java, such as cholera, bubonic plague and skin diseases [10].

In sum, pageblug in Javanese culture has wider dimension and not limited to the presence of sick or dead people. Pageblug in Javanese society is marked by following indicators:

a. many casualties (sick and died people) outside the normal range

b. social disturbance or violation of social order

c. natural disasters

d. spirits driven-phenomena. 
The understanding of miltifacet dimensionsof pageblug in Javanese culture may help the diagnosis as well as the strategy to overcome or mitigate Covid-19.

\subsection{Pageblug Mitigation}

The mitigation of pageblug in the modern era emphasizes on health aspects. The Dutch East Indies government, for instance, made efforts to overcome the outbreak influenza epidemic through laboratory research to find a cure, conducting health propaganda, and enacting influenza management laws. The Dutch East Indies Government also made various efforts, ranging from medical treatment, quarantine, to evicting slum houses during 1911-1943 pandemic [10]. The efforts, however, were colored by discrimination policy in which hospitals prioritized patients of foreign and European descents.

Among the Javanese community, the prevention of pageblug is also carried out through physical and spiritual efforts. The participation of community in overcoming pandemic was carried out through the avalaibility of herbal medicine and the improvement of health conditions [9]. This spiritual effort was also taken as approach by local societies to deal with pageblug and to face other diseases. The assumption behind spiritual approach was that disease was related to supernatural forces so that the mitigation of pageblug should involve a mystical approach. There are various approaches to dealing with disease in Javanese culture. The approaches encompasses knowledge (ngelmu), discipline (laku), medicine (jamu), and prayer or spell (japu).

\subsubsection{Ngelmu (Knowledge)}

The main spirit to overcome the turbulent era in Javanese culture is to be alert and vigilant, which mean to always remember (eling) and to be alert (waspada). Eling means remembering the Almighty and remembering one's duties as a human being. Waspada means always being aware of the signs of the times and the signs of nature. This awareness cannot be separated from ngelmu (knowledge). Eling and waspada were introduced by Ranggawarsita, a welknown writer of Javanese works in his Serat Kalatidha. He proposed both attitude as formula to face the era of wrath, or mad age due to moral decay and the disapperance of good and bad understanding [11].

In Islamic language, eling has same message to fafirru ilallah (running to God). Pageblug is a condition that is not ideal due to the damage of natural balance and social equilibrium. The safer way to escape from such situation is by returning to the embrace of God and fulfilling obligation (dharma) as His servant.

Ngelmu in Javanese culture is not only cognitive or technical knowledge, but also spiritual and awarenes to the signs of the God. Ngelmu thus encompass both knowledge and awareness from natural, social and mystical signs that enable the wise person to behave correctly. Clifford Geertz defines ngelmu in the Javanese sense as a kind of abstract knowledge, supernomal skill or substantive magical power. Knowledge has many usages and functions, such as to have people fall asleep, to find lost objects, to be rich, to know future events, and to survive in the disturbances [12].

People who have knowledge are called wong pinter (smart person). A smart person is defined as a person who has wisdom as well as knowledge of supernatural realities or knowledge of what will happen so that he will be able to defend society from further harm. Sometimes this smart person is called dukun, a traditional respected figure whose ngelmu is recognized by community. Religious persons would no be called dukun, although they are 
generally considered as wong pinter, too. This smart person is able to provide warnings and advice to the public on how to deal with calamities and pageblug.

Today, the ter, wong pinter is sufficient to be defned using old measures. Wong pinter may include person who has expertise in a certain field, like id medical treatment. In the context of pageblug, doctors are smart people who have the ability to detect, treat, and cure diseases. The concept of science is no longer sufficient to be understood merely as an interaction with supernatural forces. Scientific mastery on the nature of disease that doctors have enable them to substitute the role of dukun or traditional wong pinter. Today's wong pinter approaches health problem using modern knowledge and using technological devices. Therefore, the knowledge of dealing with pageblug today is also developing, in line with the current development of the kinds of ngelmu and the development of understanding about wong pinter.

\title{
2.2.2 Laku (Discipline)
}

In Javanese culture, to achieve success or to face trials requires discipline or self-restraint. This self-restraints range from physical action, such as reducing food-consumption and sleep, to mental-spiritual behavior, such as avoiding argue. Self-cosntraint teaching can be found in Javanese literatures. Serat Wedhatama, written by Mangkunegara IV (1984: 16-17, 35-36) from Mangkunegara Palace, states that ngelmu cannot stand alone, but must be followed by self-discipline:

\author{
Ngelmu iku \\ Kalakone kanthi laku \\ Lekase lawan kas \\ Tegese nyantosani \\ Setya budya pangekese dur angkara
}

Knowledge should

be achieved through practice

accompanied by dilligence

it means determination

and stay away from negative attitudes

The passage reinforce the importance of discipline or practice as inseparable part of knowledge. The practice is to apply knowledge with a willingness to overcome negative attitudes and temptations.

This application of discipline for overcoming bad luck can be read in a biography of President Soekarno written by Cindy Adams [13]. When he was 11 years old, he had typhus for two and a half months. Soekarno's father did mystical parctice by sleeping on the floor on a mat, right under Soekarno's bed. This practice was done to pour out his mystical power to Soekarno. The two-and-a-half month effort demonstrates a father's mental and spiritual determination to make a positive impact and to eliminate distractions from his family members.

This practice is followed by an attempt to change Soekarno's name. According to Javanese, unsuitable name will bring bad luck for the name's owner. While a child, Soekarno's name was Kusno. Because of malaria, his father change his name to be Karno. He was deemed to has objectionable or unsuitable name that give impact to his unhealth condition. Karno name, later became Soekarno, tems from a knight in Mahabharata story. Karno is Pandawa's 
brother, but he choose to take side with Kurawa to fulfill his dharma (devotion) to show thank and loyalty to Duryodono who has given him honour.

Spiritual behavior in Javanese society is mostly associated with certain rituals. Ritual is believed to be a media to tackle supernatural influence. In Desa Sumberwetan (Solo), it happened a kind of pageblug in May 2001. For 40 days, there were 15 people who died. The incident began with the death of a resident from suicide. Several other residents died subsequently without any symptom of illness. The phenomena was followed by the appearance of pocong (local ghost) figure several times [14].

The community defined the condition as pageblug and they decided to do a ritual. The ritual called mubeng deso (going around village). The ritual is carried out by walking naked together around the village at night and followed by pati geni. Pati geni (switching off lights) was a spiritual practice by turning off lights at night. To complete the ritual and to address God, the ritual was closed with tahlilan or yasinan (reciting Alquran and prayer). Despite the controversy, the practice was seen as being successful in calming things down.

According to a villager of Sumberwetan, the ritual was conducted to overcome allagedly unfavorable events and acts of spirits. He said: "The bad incident was linked to the suicide of one of the villagers. The soul of the person who committed suicide still haunts. However, after being properly buried, there are still many deaths following the suicide case. Residents suspect there is a practice of pesugihan or seeking wealth by caring for spirits by one of the residents" [14].

The residents then decided to carry out the mubeng desa ritual by ordering all the youth to guard the village alleys so that outsiders would not enter. The naked ritual was performed while chanting the mantra simultaneously and repeatedly: pring-pring petung, peli-peli buntung (petung bamboo, stumped penises). After the ritual was performed three times, slametan and tahlilan were performed because some residents did not agree with the practice. Therefore, the tahlilan becomes a means of bringing residents together, tncluding those who disagree with the ritual.

From the previous practices above, it can be concluded that discipline or practices to deal with pageblug consists of both inner and outer dimensions. Laku as an inner dimension arises from the mystical belief that pageblugs come from spiritual and social imbalances. Spiritual imbalance relates to the influence of spirits and social imbalance reflects the social problems that damages harmony. To cope with pageblug involves an inner process of strengthening the human soul and to restore the equilibrium either in social relationship or in the relationship with other beings. Laku, then, requires spiritual discipline or meditation (tapa).

In Babad Tanah Jawi, meditation was always done by leaders who underwent disaster or misfortune so that they could achieve success. Queen Kalinyamat, the sister in law of Demak King, performed naked meditation after her brother and husband were killed by the envoys of Arya Penangsang. Jaka Tingkir, King of Pajang, practiced meditation in his struggle for being accepted as officer by Demak King. Senapati, the founder of Mataram, also performed spiritual journey to the South Sea when the kingdom he built was under threat from Pajang military [15].

Other laku was manifested in ritual done by Javanese Palace. Kraton Yogyayakarta has tradition to expel Pageblug by parading banner or flag Kyai Tunggul Wulung and Kyai Pare Anom around the city. The event was attended by religious scholars who recite Quranic wordsthayyibah. Tunggul Wulung is believed to be made from the same cloth as the Kiswah (Ka'bah's cover) given by the Sultan of Turkey to Sultan Agung, the most known king of Mataram Islam. The flag is believed to have sacred and magical power that is able to ward off infectious disease outbreaks. 
Mangkunagara IV [16] highlighted the importance of laku in his Serat Wedhatama .He said:

\author{
Basa ngelmu \\ Mupakate lan panemu \\ Pasahe lan tapa \\ Yen satriya Tanah Jawi \\ Kuna-kuna kang ginilut triprakara
}

\title{
Lila lamun
}

Kelangan ora gegetun

Trima yen kataman

Sak sering sameng dumadi

Tri legawa nalangsa srah ing Bathara

The language of knowledge

It's the suit with common sense

Its efficacy is with meditation (self-restraint)

For Javanese warriors

In the past, they struggled with three things

\section{Compliant for}

Losing, without any regret

Accepting if hit (with lost)

does not get irritated with all creatures

The third compassionately surrendering to God

Knowledge, thus, needs to be associated with common sense and discipline (tapa). According to Mangkunegara IV, the practice as a spiritual discipline had always been carried out by the knights in Java for long time. The discipline referred to by Mangkunegara IV consists of three elements, namely: being compliant (lila) with tragedies; accepting (trima) without being angry at everything; and relieved) by surrendering to God [16].

These principles of disciplines are still relevant today for facing any threat and challenge, although the application of the principles should be fitted with new situation. The discipline (practice) that is taken in overcoming pegablug through willingness, acceptance, and submission to God is needed in overcoming chaos and the threat of the plague. The current implementation of the principles comply with the development of medical science and also with new medical technology.

The discipline, however, is not only connect to inner dimension of human, but also connect to outer one. In the ritual of mubeng desa, activities conducted to overcome pageblug require communal interaction. The harmony between inner and outer dimension of human as social entity is key to take care pageblug and to look for means for health. The aspects of prayer and medicine will be further discussed in the following sections.

\subsubsection{Japu / Japa Mantra (Magic Spell)}

Japu is a manifestation of the Javanese belief that prayer has power. Prayer serves as a weapon to overcome various problems and calamities and to achieve slamet (safe-condition). Javanese people exert their thoughts, actions and speech to achieve physical and mental 
salvation. The expressions of hoping for safety are often spoken in the community, such as mugo-mugo Pangeran paring slamet (may God give safety), nyangoni slamet (I give prayers for safety), ngaturaken sugeng (hopefully you are always in safety [17] and similar expressions. Prayer in Javanese society has various forms. Some of the prayers are in the form of reading magic spell in Javanese, some are in the form of tembang (traditional chanting), and some are in Arabic.

\section{a) Prayers in Javanese}

Medicine through prayer or mantra has long been known in Javanese society. Prayers or mantras are usually given by dukun or spiritual figures (ulama). The spells given by the dukun are mostly in Javanese, although some are attributed to Walisongo, popular saints in Java. In Primbon books, there are prayers or magic spell to reject illness and to get salvation, such as the prayer "Rejecting Danger to Be Safe and Safe" as follows:

Bismillahirrahmanirrakhimi, kliwatan klangkung aja wuruk sudi gawe slaman slumun slamet saka kersane Allah

Such prayers are also carried out to reject natural disasters and various diseases. Among prayer to reject the dangers of storms and winds accompanied by thunder is as follows:

Bismillahirrahmanirrakhimi, Rabbbul masriku walmaghribi, laa illah la illah huma wakukep wakela.

The prayer is a mix between Islamic-Arabic spell and anynomous chants. By reciting this prayer, Allah will give you salvation, the rain and wind will stop [18].

There is a japu or magic spell attributed to the Walisanga, in the form of a Javanese mantra. These prayers range from the prayers to reject disaster to the prayers for gaining supernatural powers. The example of prayer spelled to conquer the big storm was compiled by Wirjapanitra [19] in the Wejangan Walisanga:

\section{Bismillahirrahmanirrahim}

Hi kekilat kirta kama lara dewa kamanusan, kang mungguh ing bongkot ilat-kita, kanyatahan andikaning Nabi, sang rukun putih kang mungguh ing tengah ilat-kita, kanyatahan Rasulullah, sang kinthel putih kang mungguh ing pucuk ilat-kita, kanjatahan, kamaciyaning Allah iya iku Kang Wisesa ing braja kabeh.

The meaning spell should not analysized logicallly since the effectiveness of the spell does not lie in its hermeneutical message, rather in magical its sequence. Such japu or mantra is normally taken for granted as a cohesive structure that contains suparnatural power.

Such kinds of prayers shows strong acculturation between Islam and Javanese culture and show how the prayers are believed to have real power to overcome disturbances of spirits and to overcome natural phenomena. Prayer teachings to overcome all disturbances and threats to humans can be found in primbon works, especially those that related to the trinkets of everyday life. Some primbon are attributed to Javanese Islamic saints Walisongo shows which provides basis of legitimacy for the power of the prayer. 


\title{
b) Prayer in the Form of a Poem
}

In Javanese society, Kidung Rumekso in Wengi was recited to prevent the disturbance of spirits that appear at night until before sunrise. The kidung is believed as the work of Sunan Kalijaga. It contains strong magical powers for healing [20]. Kidung Rumekso ing Wengi is in the form of Javanese poem and it is recited as a song:

\author{
Ana kidung rumekso ing wengi \\ Teguh ayu luputa ing lara \\ Luputa bilahi kabeh \\ Jim setan datan purun \\ Paneluhan tan ana wani \\ Miwah penggawe ala \\ Gunaning wong luput \\ Geni atemahan tirto \\ Maling adoh tan ana \\ ngarah mring mami \\ Guna duduk pan sirna
}

There are chants guarding at night

Always safe, regardless of disease

All diseases are lost because of Allah

Jinns and demons don't want to (interfere)

Guns no one dared

So are evil attempts

The witchcraft from humans cannot hit

(It's like) fire is deflected by water

Thief away does not exist

Who came to me

All witchcraft will fade away

The power of Kidung Rumekso Ing Wengi cannot be separated from the assumption that the kidung was taught by Sunan Kalijaga, a great figure in Java.

In the influence of the stronger Islamic tradition, there is a praise that is sung by before the five daily prayers in mosques. In Pnademic Covid-19, the following praise is frequently heard in mosques which is believed to be able to overcome disasters::

Li khamsatun uthfi biha

Harr al-waba al-hatimah

Al-musthafa wa al-murtadha

Wabnahuma wa al-Fathimah

I have five things to put out

The heat of the plague is devastating

Prophet Muhammad (al-Musthafa) and Ali (al-Murtadla)

His second son (Hasan and Husain) and Fatima 
This praise is not a prayer arrangement from the Koran or hadith, but a reading associated with the Prophet Muhammad and his family in order to protect people from the threat of the plague. Even though it is not prorved to be sufficient to overcome Covid-19, it embodies the internalization of the religion as a means of protecting people from pandemic [21].

\section{c) Prayers in Arabic and Ruqyah}

Prayers in Arabic are practiced in Islamic societies in Java. The prayers are taken from the saying of the Prophet Muhammad and from the verses of the Koran. The students who visit the ulama usually look for prayer formula, either for safety, for looking for knowledge, or for other purposes. Prayers from ulama are generally in Arabic and are taken from the hadith or the Koran. During the Covid-19 pandemic, Islamic prayers were routinely recited the refuse to misadventure, especially after performing prayers. Among the popular prayers to reject the plague are:

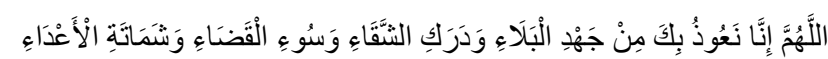

$O$ Allah, we take refuge in you from the severity of calamity, from the causes of destruction, from bad conditions, from bad consequences predestined, and from the arrogance of the enemy.

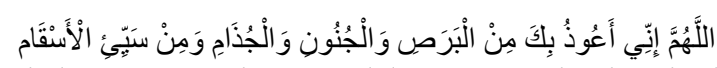

O Allah, I seek refuge in You from mottled diseases, madness and leprosy, and other bad diseases

Recently there grow Quranic therapy which is called ruqyah. Ruqyah is usually held in mosques or in houses to deal with evil spirit. During the Covid-19 pandemic, ruqyah was also advised to be used for curing covid-patients, as stated by Doctor Ahmad Zahro, former Postgraduate Director of UIN Sunan Ampel Surabaya. He argued that ruqyah could be an alternative cure for the corona virus [22]. Ruqyah is a japu with stronger Islamic influence so that the reading that is read comes from the verses of the Koran.

\subsubsection{Jamu (Herbal Medicine)}

Jamu is a popular herbal medicine in Javanese society as well as in Indonesia. The use of herbal medicine has been known for a long time, as seen in the inscription at Borobudur Temple. It is difficult to determine whether herbal medicine in Java was influenced by Chinese, Indian and Arabic medicine or developed since prehistory in Java. However, various materials used for herbal medicine come from plants that are widely grown in Java [23].

Various types of herbal medicine widenly used in Java are recorded in Serat Centini, a Javanese work dating from the late 18th or early 19th century. Serat Centini is written in poetry form and composed in an epic story, with a variety of cultural trinkets that live in Javanese society. The containtment of jamu topic in the work shows the importanct role of jamu in Javanese society. This shows that herbal medicine is an achievement of Javanese culture in the field of medicine using herbal ingredients.

Jamu, as stated by Nofita Rusdiana Dewi [9], serves as physical approach to overcome the plague in Java during the Dutch East Indies era. Jamu is a popular herbal medicine in Java. It is not surprising that at the beginning of the Covid-16 pandemic the ingredients for making herbal medicine, especially ginger, were in high demand. The use of herbal medicine was also 
encouraged by President Jokowi at the beginning of the outbreak of the Corona virus (Covid 16) in Indonesia, which led to hunting for herbal ingredients or empon-empon.

Despite being widely criticized for neglecting health procedures during a pandemic, this suggestion shows a cultural knowledge in dealing with situations that require health care. Foreign researchers, such as Susan-Jane Beers, admit that after living in Indonesia, her skepticism about the effectiveness of herbal medicine has turned into a belief [23].

Jamu is now more widely recognized in the therapy of minor diseases. Jamu is sometimes integrated into other roles, both in alternative therapy and in modern medicine. In the past, herbal medicine has become part of alternative medicine which involves non-medical therapy, even applied together with japu or magical.

Jamu may take healthy food to increase immunity. Sayur lodeh is a kind of soup consumed by local community to strengthen immunity during pandemic. The sayur lodeh consists of seven variety of vegetables, namely pumpkin, kluwih (kind of jackfruit), soy leaves, mlinjo skin, eggplant, long beans, and tempe. Each vegetable contains vitamins needed by the body. The choose of seven kind of vegetables has specific meaning, namely help, because number seven has secret function.

In modern times, the function of jamu has been largely replaced by factory medicines. Some of the herbal medicine was promoted and produced massively by herbal medicine factories, such as the Sidomuncul Factory, Jago Factory, or Nyonya Meneer Jamu Factory, which had closed in 2017.

Jamu, then, is not only herbal medicine, but also treatment with modern medicine. Currently, the efforts to overcome the pandemic cannot be separated from the use of factory drugs, such as vitamins and other medicines. The use of vitamins is optional in preventing the Covid-19 pandemic which is similiar to that of jamu. The principle is that if the body is strong and healthy, the Covid-19 virus will not easily cause a reaction.

Therefore, herbal medicine in the context of mitigating the Covid-19 pandemic may be seen in the light of variety of treatments available in society. Medicine in Javanese society is through jamu or jampi is one component, but interrellated to, other treatment approaches. In society with different level of knowledge and welfare, both traditional and modern medicine are used to strengthen social immunity to fortify themselves from the effects of Covid-19.

\subsection{The Relevance}

Cultural aspects cannot be ignored in their role in handling humanitarian problems. Plague is a humanitarian disaster that involves a human life system. Cultural values are part of social system that works in daily life of Javanese society.

The human living system is a unitary aspect of culture. Human culture includes elements of religious systems, language, social organizations, knowledge systems, systems of living equipment and technology, systems of livelihood / economy and arts. There are also those who divide the cultural dimensions into three [24], namely mentifact (mental and cognitive facts), socifact (social relationship facts), and artifacts (material human-made facts).

The Covid-19 outbreak is a health domain, but it is intertwined with other areas of life. The Covid-19 outbreak has permeated the realm of economy, social relations, religion, ethics, and politics as integral part of cultural system. In other word, mitigation of the Covid-19 outbreak is transdisciplinary involving various approaches and actors.

Javanese society makes up $40 \%$ of Indonesian people. With such extent of Indonesian society identified as Javanese, its cultural values also influence the behavior of Indonesian society. Development without paying attention to cultural dynamics will lose the ability to 
mobilize society to take social actions properly. The relevance of approaches above lies in the requirement of interdisciplinary or transdisciplinary approaches to deal with pandemic. Ignoring socio-cultural aspects will lead to the neglect of the fact that human is more complicate than machine. Human is deeply influenced by belief, hope and despair that contribute to his ability to tackle outer disturbance.

Javanese culture has a unique perspective on disasters and epidemics. Disasters and epidemics are seen as physical and spiritual phenomena that demand the synergy between the health approach and religious and social approaches. Human health is not only physical matters, but also mental ones. Mental health involves inner dimension within humans to strengthen immunity through religious beliefs, inner condition and social harmony. The Javanese cultural perspective has relevance in disaster mitigation in a transdisciplinary manner.

\section{Conclusion}

Pageblug in the view of Javanese society is more than just a physical disease. It covers all kinds of disaster ranging from natural disasters, disease outbreaks, and misery from wars. Pageblug has broad dimensions, either physical, political, social conditions, natural and spiritual ones. The basic idea of pageblug in Javanese society is a loss of harmony or a violation of certain norms that are considered sacred that lead to calamity.

The approach to pageblug is not only by medical approach, but also by non-medical one. To deal with pageblug involves not only a physical approach (herbal medicine or jamu), but also inner awareness and knowledge (ngelmu), as well as the use of inner and outer discipline (laku) and prayer (japu). In sum, pageblug mitigation in Javanese culture includes physical medicine to self-approach to God, either through prayer and reciting Alquran.

An understanding of pegablug in an integral part of social system will help in making epidemic management policies. The efforts to tackle plague or pandemics without considering the complexity of mental and social values in society may not enable comprehensive solution. The employment of transdisciplinary approach make tha chance to overcome pandemic greater.

\section{References}

[1] Almuttaqi, A. Ibrahim: "Kekacauan Respons Indonesia terhadap Covid-19" Indonesia. THC INSIGHT. No. 13/ 23 Maret; www.habiebiecenter.or.id. (2020).

[2] Aji, Rizqon Halal Syah.: "Dampak Covid -19 pada Pendidikan di Indonesia: Sekolah, Keterampilan, dan Proses Pembelajaran." Salam, Jurnal Sosial dan Budaya Syar'i Vol. 7, No. 5. (2020) Pp 395-402

[3] Aula, Siti Khadijah Nurul: "Peran Tokoh Agama dalam Memutus Rantai Pandemi Covid-19 di Media Online Indonesia." Living Islam: Journal of Islamic Discourse. Vol. 3 No. 1 (Juni 2020) p. 125-148

[4] Poerwadarminta, W.J.S; C.S. Hardjasoedarma; J.CHR. Poedjasoedira: Baoesastra Djawa. Batavia: J.B. Wolters' Uitgevers Maatschappij N.V. (1939)

[5] Kompas.News. Senin, 12 Oktober (2020)

[6] Nadzir, Mundzir: Fafirru Ilallah. Surabaya: Maktabah Ahmad Nabhan (T.Th)

[7] Anjar Any: Rahasia Ramalan Jayabaya, Ranggawarsita dan Sabdo Palon. Semarang: Aneka Ilmu (1989) 
[8] De Graaf, H.J.: Puncak Kekuasaan Mataram: Politik Ekspansi Sultan Agung. Jakarta: PT Pustaka Grafitipers (1986)

[9] Dewi, Nofita Rusdiana: "Wabah Influenza di Jawa Tahun 1918 - 1920.”Avatara, eJournal Pendidikan Sejarah. Vol 1 No. 2 Mei (2013)

[10] Cipta, Samudra Eka: "Pemerintah Hindia Belanda dalam Menghadapi Berbagai Wabah Penyakit di Jawa 1911-1943.” Equilibrium Jurnal Pendidikan Vol. VII, Issue 2, JuniDesember (2020)

[11] Wong Kam Fu, Sekretariat: Primbon Ramalan Djojobojo dan Ronggowarsito. Surabaya: P.T. Cermin (1966)

[12] Geertz, Clifford: The Religion of Java, Chicago: The University of Chicago Press (1976)

[13] Adams: Cindy. Bung Karno, Penyambung Lidah Rakyat. Jakarta dan Yogyakarta: Yayasan Bung Karno dan Media Pressindo. Cet. III. (2014)

[14] Sutiyono: Poros Kebudayaan Jawa. Yogyakarta: Graha Ilmu (2013)

[15] Olthof, W.L.: Babad Tanah Jawi: Mulai dari Nabi Adam sampai Tahun 1647.Jakarta: PT Buku Seru (2011)

[16] Mangkunegara IV: Wedhatama Karya Mangkunegara IV dan Terjemahnya. Jakarta: Prdanya Paramita (1984)

[17] Saryono, Djoko: Sosok Nilai Budaya Jawa, Rekonstruksi Normatif-Idealistis. Yogyakarta: Aditya Media Publishing (2011)

[18] No Name: Primbon Jawa Kang Ngemot Sawarnaning Primbon Karahayon. Sala: Sadu Budi (T.Th.)

[19] Wirjapanitra: Wejangan Wali Sanga. Sala: Sadu Budi (T.Th.)

[20] Sidiq, Achmad: "Kidung Rumekso ing Wengi: Studi tentang Naskah Klasik Bernuansa Islami." Jurnal Analisa Vol XV, No.1, Januari - April (2008)

[21] Zuhri, H.: "Pemaknaan Syair li Khamsatun di Tengah Pandemi Covid-19, Perspektif Living Islam.” Living Islam, Journal of Islamic Discourse. Vol. 3, No. 1 (Juli 2020) h. 149-166

[22] "Kata Guru Besar UIN Sunan Ampel, Ruqyah Bisa Sembuhkan Pasien Corona." Suara.com. Jumat 07 Februari (2020)

[23] Beers, Susan-Jane: Jamu, The Ancient Indonesian Art of Herbal Healing. Singapore: Turtle Publishing (2001)

[24] Koentjaraningrat: Pengantar Ilmu Antropologi. Jakarta: PT. Rinneka Cipta (1990) 